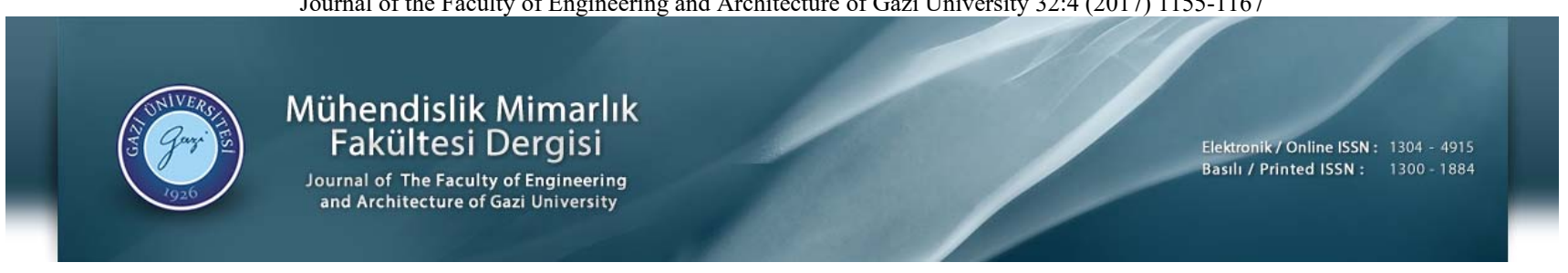

\title{
Kablosuz algılayıcı ağlarda hedef kapsama problemi için algılayıcı dağıtımı ile ağın yaşam süresinin optimizasyonu
}

\author{
Recep Özdağ*(D) \\ Yüzüncü Y1l Üniversitesi, Mühendislik Fakültesi, Bilgisayar Mühendisliği Bölümü, 65080, Van, Türkiye
}

Ö N E Ç I K A N L A R

- Hedef kapsama problemi

- Ağın yaşam süresinin optimizasyonu

- Meta-sezgisel algoritma ile algılayıcı dağıtımı

Makale Bilgileri

Geliş: 18.07.2016

Kabul: 10.07.2017

DOI:

10.17341/gazimmfd.369516

Anahtar Kelimeler:

Kablosuz algılayıcı ağlar, hedef kapsama problemi, k-kapsam gereksinimi, ağ yaşam süresi, algılayıcı dağıtımı

\section{ÖZET}

Ağ yaşam süresi Kablosuz Algılayıcı Ağ (KAA)'ların etkinliğini belirleyen kritik bir faktördür. Askeri ve sivil uygulamalarda KAA'ların kapsanmasının sürekliliği açısından hedefleri izleyen algılayıcı düğümlerin pil ömürlerinin optimizasyonu ağın yaşam süresinin uzatılmasında önemli bir rol oynar. KAA'ları olușturan algılayıcı düğümlerin sınırlı pil ömürleri bulunduğu için algılayıcıların kendi aralarında haberleşmeleri ve ilgili alanı algılamaları neticesinde enerjileri gittikçe azalır. Nihayetinde düğüm enerjisini tamamıyla tüketerek KAA'nın işlevini yerine getirememesine neden olur. Bu sebeple KAA'ların yaşam sürelerinin optimizasyonu literatürde sıklıkla çalışılan konulardan biri olmuştur.Bu makalede KAA'lardaki hedef kapsama problemine çözüm bulmak için hedeflerin maksimum dört algılayıcı düğüme kadar olan kapsama gereksinimlerinin $(1 \leq \mathrm{k} \leq 4)$ sağlanması şartıyla, düğümlerin dinamik dağıtımları yapılarak ağın yaşam süresinin optimizasyonu amaçlanmıştır. Hedeflerin kapsama gereksinimleri sağlandığı anda düğümlerin kalan pil ömürleri ile ağın yaşam süresinin üst sınırı hesaplanarak ağın ulaşılabilir yaşam süresinin tespiti hedeflenmiştir. Ayrıca algılayıcı düğümlerin dinamik dağıtımlarının yapılmasında meta-sezgisel olan Elektromagnetizma - Benzer (EM) algoritması temel alınmış ve enerji verimli yeni bir algoritma geliștirilmiş̦tir. Bu algoritma ile hesaplanan ulaşılabilir ağ yaşam süreleri literatürdeki Yapay Arı Kolonisi (ABC) ve Parçacık Sürü Optimizasyonu (PSO) algoritmaları ile karşılaştırılmıştır. Ulaşılan benzetim sonuçlarına göre ağın yaşam süresinin üst sınırına ulaşmada geliştirilen algoritmanın daha optimum sonuçlar verdiği tespit edilmiştir.

\section{The optimization of network lifetime with sensor deployment for target coverage problem in wireless sensor networks}

\section{H I G H L I G H T S}

- $\quad$ Target Coverage Problem

- Optimization of the network's lifetime

- Sensor deployment with meta-heuristic algorithm

Article Info

Received: 18.07.2016

Accepted: 10.07.2017

DOI:

10.17341/gazimmfd.369516

Keywords:

Wireless sensor networks, target coverage problem, $\mathrm{k}$-coverage requirement, network lifetime, sensor deployment

\begin{abstract}
Network lifetime is a critical factor in determining the effectiveness of Wireless Sensor Networks (WSNs). The optimization of the battery lives of the sensor nodes following the targets in terms of continuity of WSNs coverage in military and civil applications plays an important role in extending the network's lifetime. Since the sensor nodes that constitute WSNs have limited battery life, the energy of the sensors gradually decreases as a result of communicating among themselves and perceiving field of interest. Ultimately, the node consumes its energy completely and causes WSN to fail to function. For this reason, the optimization of the lifetime of WSNs has been one of the most frequently studied topics in the literature.In this article, it was aimed to optimize the lifetime of the network by performing dynamic distributions of the nodes provided that the coverage requirements $(1 \leq \mathrm{k} \leq 4)$ of the maximum four sensor nodes are met to find solution to the target coverage problem in WSNs. It was aimed to determine the accessible lifetime of the network by calculating the remaining battery life of the nodes and the upper limit of the network lifetime when the coverage requirements of the targets are met. In addition, ElectromagnetismLike (EM) algorithm, which is meta-heuristic in performing the dynamic distributions of sensor nodes, was taken as a basis, and a new energy-efficient algorithm was developed. The accessible network lifetimes calculated with this algorithm were compared with the Artificial Bee Colony (ABC) and Particle Swarm Optimization (PSO) algorithms in the literature. According to the obtained simulation results, it was found that the algorithm developed in reaching the upper limit of the network lifetime gave more optimum results.
\end{abstract}




\section{GIIRISŞ (INTRODUCTION)}

KAA'lar ulusal güvenliği gerektiren askeri ve sivil ortamın izlenmesi, otoyollarda trafiğin izlenmesi, fabrika üretim aşamasında otomasyonun izlenmesi, tarım alanında çevrenin izlemesi gibi çeşitli alanlardaki uygulamalarda önemli derecede kullanılmaktadır [1]. KAA'ları oluşturan algılayıcı düğümlerin enerji tüketimleri ağın yaşam süresini belirleyen kritik faktörlerden biridir. Düğümlerin enerjilerinin verimli bir şekilde kullanımı sayesinde ağın yaşam süresi uzatılarak hedeflerin sürekli olarak izlenmesi sağlanabilir. Dolayısıyla sınırlı bir enerjiye sahip olan ve daha sonradan bataryaları şarj edilemeyen veya değiştirilemeyen algılayıcıların enerji tüketimlerinin minimize edilmesi sonucunda ağın yaşam süresi optimize edilir [2]. Fakat dügümmler enerjilerini hızlı bir şekilde tüketmeleri durumunda, planlanandan daha kısa bir süre sonra dügü̈mler pasif hale geçerek kapsadığ 1 hedefleri algılayamaz duruma gelir.

KAA'larda hedef kapsama problemi kapsam gereksiniminin sağlanması amaciyla ilgili alandaki hedeflerin yeterli sayıda algılayıc1 düğüm ile kapsanamamasından kaynaklanabilmektedir. Herhangi bir hedef noktası için kapsama gereksiniminin sağlanması, o hedef noktasının tanımlanan sayıda düğüm tarafından kapsanması anlamına

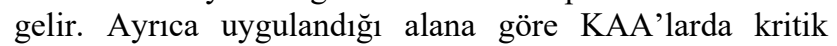
hedeflerin sürekli olarak izlenebilmesi için bu hedeflerin birden fazla düğüm tarafından kapsanmasının garanti edilmesi gerekir. Çünkü düğümlerden biri enerjisini tüketse dahi o hedefi kapsayan diğer düğüm bu hedefin izlenmesindeki sürekliliği sağlayacaktır. Dolayısıyla hedefler için minimum kapsama gereksiniminin sağlanması, hedeflerin istenilen güvenirlikte izlendiğini garanti edecektir.

Hedef kapsama; basit kapsama, $k$-kapsama ve $Q$-kapsama olarak sınıflandırılır [3]. Basit kapsama; alandaki her bir hedefin en az 1 adet algılayıcı düğüm tarafindan kapsanmasını ifade eder. $k$-kapsama [1]; her bir hedefin tanımlanacak olan en az $k$ adet algılayıcı düğüm tarafindan kapsanmasını ifade eder. $Q$-kapsama [4] ise, $n$ hedef sayısı ve $1 \leq \mathrm{j} \leq n$ olmak üzere hedef vektörü $\mathrm{T}=\left\{\mathrm{T}_{1}, \mathrm{~T}_{2}, \ldots\right.$, $\left.\mathrm{T}_{\mathrm{n}}\right\}$ 'nin tanımlanacak olan kapsam vektörü $\mathrm{Q}=\left\{\mathrm{q}_{1}, \mathrm{q}_{2}, \ldots\right.$, $\left.\mathrm{q}_{n}\right\}$ ile her hedef $\mathrm{T}_{\mathrm{j}}$ 'nin en az $\mathrm{q}_{j}$ algılayıcı düğüm tarafindan kapsanmasını ifade eder.

Şekil 1'de $T_{1}$ ve $T_{2}$ hedef noktalarının $S=\left\{S_{1}, S_{2}, S_{3}, S_{4}\right\}$ algılayıc1 kümesi tarafindan kapsanma durumları gösterilmiştir. İlgili alandaki $\mathrm{T}$ hedef noktalarının $1 \leq \mathrm{i} \leq 4$ olmak üzere $\mathrm{S}_{\mathrm{i}}$ düğümü tarafından kapsanma şartı; $d\left(\mathrm{~T}, \mathrm{~S}_{\mathrm{i}}\right) \leq$ $r_{i}$ olmasıdır. Verilen eşitlikte $d$ Öklid (Euclidean) mesafesini [1], $r$ ise düğümün algılama yarıçapını gösterir. Eğer T hedef noktası $\mathrm{S}_{\mathrm{i}}$ düğümünün algılama aralığı içine konumlanmış ise, bu hedefin $S_{i}$ düğümü tarafindan kapsandığı tespit edilir. Dolayısıyla herhangi bir hedef noktasının S kümesindeki en az iki düğümün $(k \geq 2)$ kapsama alanlarının kesişim bölgesinde bulunması; bu hedefin birden fazla düğüm tarafından kapsandığı ve düğümlerden birisi pasif duruma geçse bile diğer düğüm tarafından kapsamanın devam edeceği anlamına gelir. Şekil 1'de verilen durum için T hedef noktalarının en az $3(k \geq 3)$ düğüm tarafından kapsandığı söylenebilir. $T_{1}$ hedef noktas1 $\left\{\mathrm{S}_{1}, \mathrm{~S}_{2}, \mathrm{~S}_{4}\right\}$ tarafindan kapsanırken, $T_{2}$ hedef noktas1 ise $\left\{S_{1}, S_{3}, S_{4}\right\}$ tarafindan kapsanmaktadır.

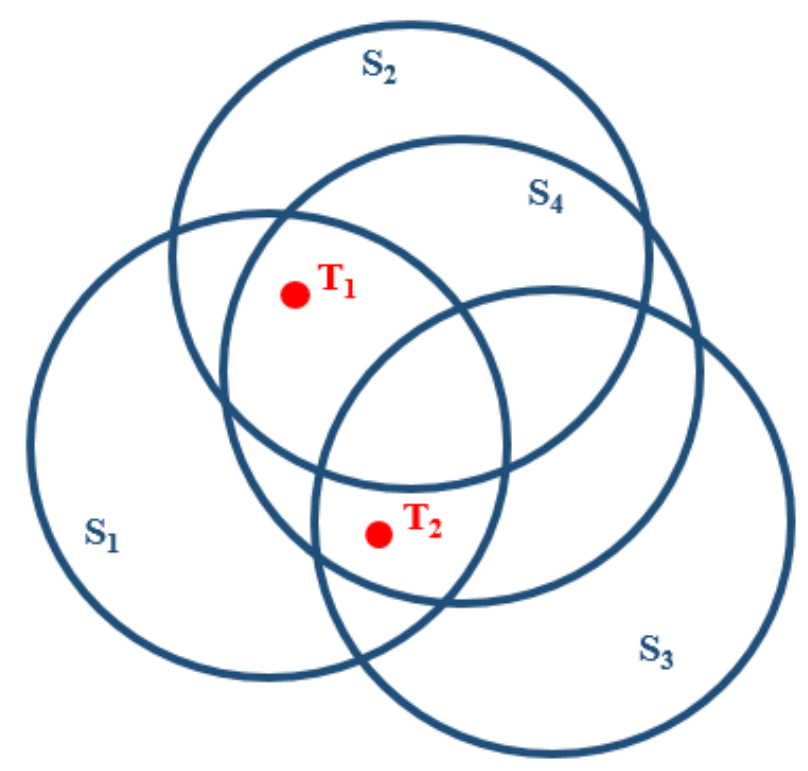

Şekil 1. Hedef Kapsama Örneği (An Example of Target Coverage)

Algılayıcı düğ̈̈mlerin ilgili alanın tümünü veya belirli hedef noktalarını kapsaması amacıyla dügümlerin alandaki optimum konumlarının tespiti ağın kapsama alanı ve yaşam sürelerinin optimizasyonunda her zaman belirleyici bir faktör olmuştur. Düşük kapsama düzeyi (basit kapsama) ev güvenliği gibi uygulamalarda veya tarımsal çevrenin izlenmesinde yeterli olabilmektedir. Yüksek kapsama düzeyi ( $k$-kapsama) [5] hedeflerin sürekli olarak izlenmesini gerekli kılan hedef takibi uygulamalarında veya savaş bölgeleri, kimyasal kirlilik alanları gibi düşman ortamların takibinde gerekli olabilmektedir. Daha yüksek kapsama düzeyi $(Q$ kapsama) [6] ise, düşman bölgelerinin takibi veya nükleer tesis gibi daha hassas hedeflerin çoklu algılayıcı düğümler tarafindan izlenmesini sağlamak için video gözetleme uygulamalarında gerekli olabilmektedir. Dolayısıyla kapsama gereksiniminin tespiti KAA'ların uygulama alanlarına göre farklılık gösterebilmektedir.

$\mathrm{Bu}$ çalışmada, meta-sezgisel olan EM algoritması ile Maksimum Yaşam Süresini temel alan Hedef Kapsama Algoritmas1 (Target Coverage Algorithm based on Maximum Lifetime with Electromagnetism-Like - TCAMLEM) geliştirilerek algılayıcı düğümlerin dinamik dağıtımı yapılmıştır. Yapılan dağıtımda tüm hedeflerin $k$-kapsam gereksinimleri sağlandığ̣ anda düğümlerin kalan yaşam süreleri belirlenerek ağın ulaşılabilir yaşam süresi hesaplanmıştır. TCAML-EM'nin elde edilen benzetim sonuçları $\mathrm{ABC}$ ve PSO algoritmaları ile karşılaştırılarak geliştirilen algoritmanın performansı değerlendirilmiştir. 


\section{2. İLGİLI ÇALIŞMALAR (RELATED WORKS)}

Algılayıcı düğümlerin dinamik dağıtımları ve hedef kapsama problemi üzerine literatürde birçok çalışma yapılmıştır. Celal vd. [7, 8] İkili Tarama Modeli (Binary Detection Model) ve Olasilıksal Tarama Modeli (Probabilistic Detection Model)'ni kullanarak geliştirdikleri ABC algoritmasını düğümlerin dinamik dağıtımlarına uygulayarak ağın kapsama alanını optimize etmeye çalışmışlardır. Recep ve Ali [9, 10] ilgili alanın kapsanma oranını artırmak için EM algoritmasını kullanarak geliştirdikleri yeni bir dinamik dağıtım metodu ile dügüumlerin konumlarını optimize ederek kısmen de olsa ağın yaşam süresini uzatmışlardır. Ayrıca Feyza ve Suat [11] çok amaçlı evrimsel algoritmalar ile mobil düğümlerin dinamik dağıtımlarını yaparak KAA'ların kapsama alanını optimize etmişler ve düğümlerin yer değiştirme mesafelerinin optimizasyonunu sağlayarak algılayıcıların enerji tüketimlerini minimize etmişlerdir. Literatürde alan kapsama (area coverage) olarak ifade edilen çalışmalar sadece tüm alanının kapsanmasını optimize etmeye yönelik olduğu için dinamik dağıtımı yapılan dügüumler ile ilgili alanın kapsanma oranı artırılmaya çalışılmıştır. Ayrıca kapsama problemlerinin başlıca amaçlarından bir diğeri de ağın yaşam süresini artırmak olduğu için düğümlerin enerji tüketimlerini optimize etmek amaciyla hedef kapsama (target coverage)'ya yönelik olarak literatürde birçok çalışma yapılmıştır. Onur vd. [12] algılayıcı dağıtım kalitesinden bahsederek dağıtımın yeterli kapsamayı sağlayıp sağlamadığını veya yeniden dağıtımın gerekli olup olmadığını gösteren kaliteli ölçümü önermişlerdir. Cheng vd. [13] etkin nokta (hot spot) problemlerini azaltarak ağın yaşam süresini optimize eden algılayıcı dağıtım stratejisini [14] incelemişlerdir. Mini vd. [15] basit kapsama problemini çözmek için ABC algoritmasını kullanmışlar ve bu çalışmalarını [16]'da geliştirerek $k$ ve $Q$ kapsama problemlerine uygulamışlardır. $\mathrm{Bu}$ çalışmadaki amaçları gerekli algılama aralığı minimum olacak şekilde düğümlerin ilgili alanda dinamik dağıtımlarını yaparak yerleştirmektir. Ayrıca [3]'deki çalışmalarında meta-sezgisel algoritmalar ile algılayıcı düğümlerin dinamik dağıtımlarını yaparak ağın yaşam süresinin üst sınırını hesaplamışlardır. Udgata vd. [17] düzgün olmayan arazide algılayıcı dağıtım problemi için ABC algoritmasından faydalanarak bir çalışma yapmışladır. Amaç algılayıcıların algılama aralığı gereksinimlerini minimize ederek enerjilerini muhafaza etmektir. Mini vd. [18] ağın yaşam süresini maksimize etmek için algılayıcı düğümlerin ilgili alandaki çalışma düzenlerini planlayan bir sezgisel algoritma önermişlerdir. Liu vd. [19, 20] bir düğümün bir zaman anında sadece bir hedefi izleyebileceği varsayımı ile $k$-kapsama problemini çalışmışlardır.

\section{TEORİK METOT (TEORICAL METHOD)}

\subsection{Problem Tanımı (Problem Definition)}

İlgili alanda $n$ adet hedef noktasından oluşan $\mathrm{T}=\left\{\mathrm{T}_{1}, \mathrm{~T}_{2}, \ldots\right.$, $\left.\mathrm{T}_{\mathrm{n}}\right\}$ kümesi ve $m$ adet mobil algılayıcı düğümden oluşan $\mathrm{S}=$ $\left\{\mathrm{S}_{1}, \quad \mathrm{~S}_{2}, \ldots, \mathrm{S}_{\mathrm{m}}\right\} \quad$ kümesi tanımlanmıştır. $k$-kapsama derecesine göre kapsama gereksinimi sağlanacak şekilde T kümesindeki tüm hedeflerin $\mathrm{S}$ kümesindeki en az $k$ adet algılayıcı düğüm tarafından kapsanabilmesi ve ağın yaşam süresinin maksimize edilebilmesi bu çalışmadaki $k$-kapsama problemini tanımlar.

\subsection{Hedef Kapsama Gereksinimi (Target Coverage Requirement)}

Tüm hedefler için tanımlanan $k$-kapsama gereksinimi sağlanacak şekilde algılayıcı düğümlerin dinamik dağıtımlarının yapılabilmesini tanımlar. Alandaki her bir hedef için kapsam gereksinimi basit kapsama ve $k$-kapsama şeklinde sınıflandırılarak belirlenir.

\subsubsection{Basit-kapsama için algılayıcı dağıtımı (Sensor deployment for simple-coverage)}

Alandaki konumları rastgele olarak belirlenen $\mathrm{T}$ kümesindeki her bir hedefin $\mathrm{S}$ kümesindeki en az bir algılayıcı düğüm $(k \geq 1)$ tarafından kapsanacak şekilde düğümlerin dağıtımlarının yapılabilmesini tanımlar.

\subsection{2. k-kapsama için algılayıcı dağıtımı \\ (Sensor deployment for k-coverage)}

Alandaki konumları rastgele olarak belirlenen $\mathrm{T}$ kümesindeki her bir hedefin S kümesindeki en az $k$ algılayıc1 düğüm tarafindan kapsanacak şekilde dügüümlerin dağıtımlarının yapılabilmesini tanımlar.

\subsection{Algılayıcı Ăğn Maksimum Yaşam Süresi \\ (Maximum Lifetime of Sensor Network)}

Hedeflerin kapsama gereksinimlerinin sağlanması sürecinde ağın yaşam süresinin üst sınırına ulaşabilmek için hedefleri kapsayan düğümlerin maksimum yaşam sürelerini tanımlar. Düğümlerin dağıtımı sonrasında hedef noktaların kapsanma durumlarının tespit edilmesi gerekmektedir. İlgili alanda her bir algılayıcı düğümün $E_{0}$ başlangıç enerjisine ve birbirine eşit $r$ değerine sahip olduğu varsayılarak; $1 \leq \mathrm{j} \leq n$ ve $1 \leq \mathrm{i} \leq$ $m$ olmak üzere $\mathrm{S}_{\mathrm{i}}$ ile $\mathrm{T}_{\mathrm{j}}$ arasındaki $d$ mesafesi $r$ mesafesinden daha küçük ise, $S_{i}$ dügüumünün $T_{j}$ hedefini kapsadığı kabul edilir. Her bir $T_{j}$ hedefinin $S_{i}$ düğümler tarafından kapsanma durumunu gösteren kapsama matrisi Eş. 1 [3] ile oluşturulur.

$M_{i j}=\left\{\begin{array}{l}1, \quad \text { ĕgerd }\left(S_{i}, T_{j}\right) \leq r \\ 0, \quad \text { aksi durumda }\end{array}\right.$

Hedef noktalarını kapsayan dügüümlerin kalan enerjileri Eş. 2 [3] kullanılarak hesaplanır.

$b_{i}^{\prime}=\frac{b_{i}}{e_{i}}$

Verilen eşitlikte $\mathrm{S}_{\mathrm{i}}$ düğümünün mevcut enerjisi $b_{i}$, enerji tüketim oranını ise $e_{i}$ ile temsil edilmiştir. $\mathrm{S}_{\mathrm{i}}$ düğümünün hedefleri kapsaması sonrasında kalan enerjisi $b_{i}^{\prime}$ azalacaktır. $b_{i}^{\prime}=0$ ise, bu düğ̈̈m enerjisini tamamıyla tükettiği için pasif konuma geçerek ilgili alandaki hedefleri algılayamayacaktır. Ağın yaşam süresinin üst sınırı ulaşılabilir ă̆ yaşam süresini ifade eder ve Eş. $3[3,4,6]$ ile hesaplanır. 
$U=\min _{j}\left[\frac{\sum_{i} M_{i j} \times b_{i}^{\prime}}{q_{j}}\right], q_{j}>=k$

Verilen eşitlikte $q_{j}$ her bir $T_{j}$ hedef noktasını kapsayan minimum $k$ değerine eşittir. Buna göre her bir $\mathrm{T}_{\mathrm{j}}$ hedef noktası için hesaplanan yaşam sürelerinin minimum olanı esas alınarak ağın yaşam süresinin üst sınırı (U) hesaplanır. Dolayısıyla ilgili alanda minimum yaşam süresine sahip olan dügümler tarafından kapsanan hedefler için hesaplanan yaşam süresi o ağın ulaşılabilir yaşam süresini belirler.

\section{4. ÖNERİLEN YÖNTEM (PROPOSED METHOD)}

\subsection{EM Algoritmasl (EM Algorithm)}

Çözüm uzayında elektromanyetik alandaki parçacıkların kendi aralarındaki itme-çekme hareketlerini taklit eden, gerçek değerli doğrusal olmayan problemleri optimize etmek amacıyla Birbil ve Fang [21] tarafından geliştirilen ve popülasyonu esas alan meta-sezgisel [22, 23] bir algoritmadır. Her parçacık belirli miktarda taşıdığı yük ile popülasyonun diğer üyelerine itme veya çekme kuvvetleri uygular. Dolayısıyla EM algoritması örnek noktaları optimuma daha yakın yerleştirmek için itme-çekme mekanizmasından faydalanır. Herhangi bir parçacığa diğer parçacıklar tarafindan uygulanan kuvvetlerin toplamı alınarak oluşan bileşke kuvvet yönünde bu parçacığın hareket etmesi sağlanır. Böylece çözüm uzayında parçacıkların optimum çözüme yönelik olarak konumlarının güncellenmesi sağlanır [24]. EM algoritması meta-sezgisel olması sebebiyle her bir parçacığın uygunluk fonksiyon (fitness function) değerleri belirlenerek parçacıkların yük değerleri hesaplanır. Çözümü yapılacak olan probleme göre uygunluk fonksiyonu tespit edilir [25]. Eş. 4'te verilen sınırlı değişkenler ile EM algoritması optimizasyon problemlerine uygulanır $[9,10]$.

$$
\begin{aligned}
& f(x), x \in R \\
& R=\left\{\begin{array}{c}
x \in \Re^{c u} \mid l_{c u} \leq x_{s} \leq u_{c u}: l_{c u}, u_{c u} \in \Re, \\
s=1, \ldots, n_{c u}
\end{array}\right\}
\end{aligned}
$$

Verilen eşitlikte çözüm uzayında her bir parçacık olan $\mathrm{x}$, yükün uygunluk fonksiyonuna bağlı olduğu bir çözümü temsil eder. $n_{c u}$ çözüm uzayının boyutunu, $l_{c u}$ çözüm uzayının alt sınırını, $u_{c u}$ çözüm uzayının üst sınırını ve $\mathrm{f}(\mathrm{x})$ ise minimize edilecek olan uygunluk fonksiyonunu gösterir [25]. Tablo 1'de taslak kodu [10] sunulan EM algoritmas1 sirası ile başlatma, yerel arama, hesaplama ve hareket etme isimleri ile adlandırılan 4 alt programdan oluşur.

\subsubsection{Başlatma alt programı (Initialization subprogram)}

Çözüm uzayındaki parçacıkların konumlarının rastgele olarak üretildiği yordamdır $[10,21]$. Öncelikle bazı parametrelerin tanımlanması gerekir. $\mathrm{Bu}$ parametreler; popülasyon sayıs1 $\left(N_{p r t}\right)$, iterasyon sayıs1 $\left(M_{\text {iterasyon }}\right), n_{c u}$ 'dur. Popülasyondaki $N_{\text {prt }}$ parçacığın dağıtımı rastgele bir şekilde $n_{c u}$ boyutlu çözüm uzayının üst ve alt sınırı arasında Tablo 2'deki taslak kod [21] esas alınarak yapılır. Ayrıca çözüm uzayında dağıtımı yapılan her bir parçacığın $f(x)$ 'i hesaplanarak optimum parçacık olan $\mathrm{x}^{\mathrm{opt}}$ tespit edilir.

Tablo 1. Genel EM algoritmas1 (General EM algorithm)

\begin{tabular}{ll}
\hline 1: & Başlatma() \\
2: & iterasyon $\leftarrow 1$ \\
3: & while iterasyon $\leq M_{\text {iterasyon }}$ do \\
4: & Yerel örnek noktaları arama() \\
5: & Parçacıkların yük ve toplam kuvvetini hesaplama() \\
6: & Parçacıkları bileşke kuvvet yönüne doğru hareket \\
7: & ettir() \\
8: & end while \\
\hline
\end{tabular}

Tablo 2. Popülasyonu başlatma taslak kodu (Population initialization draft code)

\begin{tabular}{ll}
\hline $1:$ & for $\mathrm{i}=1$ to $N_{\text {prt }} d o$ \\
2: & for $\mathrm{j}=1$ to $n_{c u} d o$ \\
3: & $\lambda \leftarrow \operatorname{random}(0,1)$ \\
4: & $\mathrm{x}_{\mathrm{j}}^{\mathrm{i}} \leftarrow l_{j}+\lambda\left(u_{j}-l_{j}\right)$ \\
5: & end for \\
6: & $\mathrm{f}\left(\mathrm{x}^{\mathrm{i}}\right)$ hesapla \\
7: & end for \\
8: & $\mathrm{x}^{\text {opt } \leftarrow \operatorname{argmin}\left\{\mathrm{f}\left(\mathrm{x}^{\mathrm{i}}\right), \mathrm{Vi}\right\}}$ \\
\hline
\end{tabular}

\subsubsection{Yerel arama alt programı (Local search subprogram)}

Çözüm uzayındaki $\forall i$ örnek noktasındaki $x^{i}$ parçacığg için komşu bilgileri toplamda kullanılır [10]. Yeni bir parçacık olan $\mathrm{y}$, maksimum rastgele adım uzunluğu olan $\delta$ ile $\mathrm{x}^{\mathrm{i}}$ parçacığının yönü boyunca hareket ettirilir. Eğer y en iyi $f\left(x^{i}\right)$ değerine ulaşır ise, $x^{i}$ parçacığ süreç genellikle fazla zaman harcadığından dolayı bu alt program gerekli değildir ve göz ardı edilebilir [21, 26].

\subsubsection{Hesaplama alt programı (Calculation subprogram)}

Popülasyondaki Vi parçacığın q $\mathrm{q}^{\mathrm{i}}$ yükünün ve sonrasında bu parçacıklara uygulanacak olan toplam kuvvetin hesaplandığ 1 yordamdır. Her iterasyonda parçacıkların $f\left(x^{i}\right)$ değerlerine göre $\mathrm{q}^{\mathrm{i}}$ yük değerleri hesaplanır. Tablo 3'de verilen taslak koda [21] göre, $\forall i$ parçacığın hesaplanan $q^{i}$ değeri, $x^{i}$ parçacığının diğer parçacıklara uygulayacağı itme-çekme kuvvetini belirler. Bu taslak kodun 8.adımındaki eşitliğe göre (süper pozisyon ilkesi [21]); diğer parçacıklar tarafından $\mathrm{x}^{\mathrm{i}}$ 'nci parçacığa uygulanan kuvvet parçacıkların yükleri ile doğru orantılı ve parçacıkların arasındaki mesafeler ile ters orantılı olarak değişir. Ayrıca daha iyi $\mathrm{f}(\mathrm{x})$ değerine sahip olan parçacık bir diğer parçacığı kendisine doğru çeker (8.adım), daha kötü $\mathrm{f}(\mathrm{x})$ değerine sahip olan parçacık ise bir diğer parçacı̆̆ 1 iter $(9 . \operatorname{ad} 1 m)$. $x^{\text {opt }}$ olan parçacık minimum $\mathrm{f}(\mathrm{x})$ değerine sahip olduğu için popülasyondaki diğer tüm parçacıkları kendisine doğru çekerek mutlak bir çekim noktası gibi davranır. Dolayısıyla diğer parçacıklar tarafından $\mathrm{x}^{\mathrm{i}}$ 'nci parçacığa uygulanan kuvvetlerinin toplamı alınarak toplam $\mathrm{F}^{\mathrm{i}}$ hesaplanır. 
Tablo 3. Yük ve toplam kuvvet hesaplama taslak kodu (Charge and total force calculation draft code)

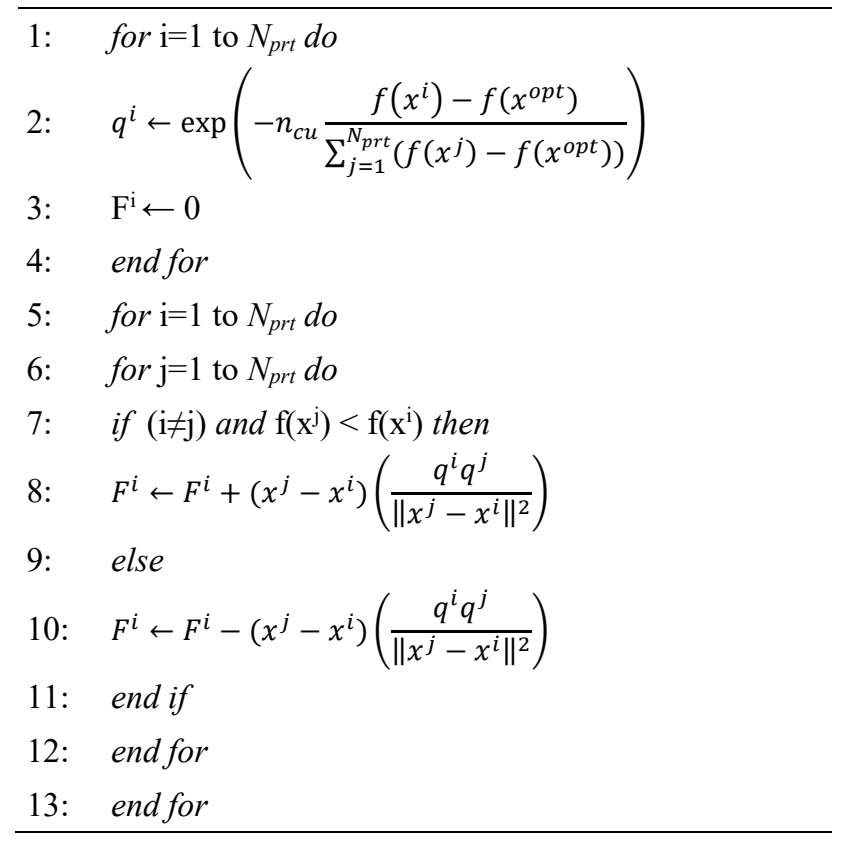

\subsubsection{Hareket etme alt programı (Movement subprogram)}

Hesaplama alt programında $\mathrm{x}^{\mathrm{i}}$ ’nci parçacı̆̆a uygulanan kuvvetlerin toplamı alınıp oluşan bileşke vektör yönünde hareket ederek mevcut konumunun güncellendiği yordamdır $[10,21]$. "optimum parçacık" olarak adlandırılan $\mathrm{x}^{\mathrm{opt}}$ diğer tüm parçacıkları kendisine doğru çektiğinden için Tablo 4'te verilen taslak kod [21]'un 2.adımına göre bu parçacığın konumu değiştirilmez. Eğer $x^{i}$ ’nci parçacığa uygulanan toplam $\mathrm{F}^{\mathrm{i}}>0$ ise, taslak kodun 6.adımına göre çözüm uzayının üst sınırına doğru pozitif yönde hareket eder, aksi durumda ise taslak kodun 8.adımına göre çözüm uzayının alt sınırına doğru negatif yönde hareket ederek mevcut konumunu günceller.

Tablo 4. Hareket etme taslak kodu (Movement draft code)

\begin{tabular}{ll}
\hline $1:$ & for $\mathrm{i}=1$ to $N_{\text {prt }} d o$ \\
$2:$ & if $(\mathrm{i} \neq \mathrm{opt})$ then \\
$3:$ & $\lambda \leftarrow \operatorname{random}(0,1)$ \\
4: & for $\mathrm{j}=1$ to $n_{c u} d o$ \\
5: & if $\mathrm{F}_{\mathrm{j}}^{\mathrm{i}}>0$ then \\
6: & $x_{j}^{i} \leftarrow x_{j}^{i}+\lambda\left(\frac{F_{j}^{i}}{\left\|F^{i}\right\|}\right)\left(u_{j}-x_{j}^{i}\right)$ \\
7: & else \\
8: & $x_{j}^{i} \leftarrow x_{j}^{i}+\lambda\left(\frac{F_{j}^{i}}{\left\|F^{i}\right\|}\right)\left(x_{j}^{i}-l_{j}\right)$ \\
9: & end if \\
10: & end for \\
11: & end if \\
12: & end for \\
\hline
\end{tabular}

4.2. Maksimum Yaşam Süresini Temel Alan Hedef Kapsama Algoritmasl (Target Coverage Algorithm Based On Maximum Lifetime)

Algılayıcı düğümlerin ilgili alanda rastgele dağılımları sonrasında hedef noktaların tanımlanan aralıktaki $k$-kapsam gereksinimleri sağlanması şartıyla bu düğümlerin deterministik dağıtımları yapılarak maksimum ă̆ yaşam süresine ulaşılması amaçlanmıştır. Dolayısıyla alandaki tüm hedef noktaların minimum enerji tüketimi ile kapsanması esas alınarak ağın yaşam süresinin optimizasyonu hedeflenmiştir. TCAML-EM'nin tasarlanmasında iki temel aşama kullanılarak bu algoritma geliştirilmiştir.

Birinci aşamada düğümlerin rastgele dağıtımları sonrasında meta-sezgisel olan EM algoritması kullanılarak düğümlerin dinamik dağıtımları yapılmıştır. Şekil 2'de gösterilen TCAML-EM'nin akış diyagramına göre tüm hedeflerin kapsam gereksinimi tanımlanan $1 \leq k \leq 4$ aralığında sağlanamadığı sürece optimum olmayan dügüumlerin dinamik dağıtımları yeniden yapılarak optimum çözüme doğru düğümlerin yeniden konum değiştirmesi sağlanır. İkinci aşamada yeni bir yöntem olarak geliştirilen TCAMLEM ile hedeflerin $k$-kapsama gereksinimi sağlanarak ağın yaşam süresi uzatılmaya çalışılmıştır. Öncelikle bu problemin çözümüne binaen her bir algılayıcı düğüme atanan başlangıç yaşam süreleri esas alınarak düğümlerin $\mathrm{f}\left(\mathrm{x}^{\mathrm{i}}\right)^{\prime} \mathrm{i}$ belirlenir. Sonrasında ise, $k$-kapsam gereksinimi sağlandığı anda düğümlerin kalan yaşam sürelerine göre her bir hedefi kapsayan düğümlerin ortalama yaşam süreleri hesaplanır. Bu sürelerin minimum olanı belirlenerek ağın yaşam süresinin üst sınırı tespit edilir. Dolayısıyla yapılan her benzetim çalışmasında bu üst sınır hesaplanarak ağın ulaşılabilir yaşam süresi belirlenir.

İlgili alandaki algılayıcı dügümlerin ve kapsanacak olan hedeflerin konumları daha güvenilir sonuçlara ulaşabilmek amacıyla rastgele olarak seçilmiştir. Eğer düğümler kapsadığ 1 hedef noktası için $k$-kapsama gereksinimini sağlıyor ise, yani $k$-kapsama derecesine göre bir hedef noktası en az $k$ adet düğüm tarafından kapsanıyor ise, o hedef noktasını kapsayan düğümler optimum olarak tanımlanır. Optimum dügüum; herhangi bir hedef noktası için $k$-kapsam gereksinimini sağlayarak optimum konuma yerleşen ve o andan itibaren statik olarak tanımlanan algılayıcıdır. Optimum düğüm sayesinde benzetim çalışmasının başlangıcından itibaren $k$-kapsama gereksinimine göre hedeflerin çoğunun hızlı bir yakınsama ile kapsanması gerçekleştirilir. Sadece hedefleri kapsayan düğümlerin yaşam süreleri enerji tüketim oranında azaltılarak bu düğümlerin $\mathrm{f}\left(\mathrm{x}^{\mathrm{i}}\right)$ güncellemesi yapılır. $\mathrm{Bu}$ süreçte bazı düğümlerin yaşam süreleri tamamen tükenebilir. $\mathrm{Bu}$ durumda; düğüm pasif duruma geçerek ağdan düşürülür. Tüm hedefler tanımlanan $k$ adet düğüm tarafından kapsandığ 1 anda artık $k$-kapsama gereksinimi sağlanacağ için ağın ulaşılabilir yaşam süresi hesaplanır. Dolayısıyla TCAML-EM ile hedeflerin $k$-kapsama gereksinimi daha kısa sürede sağlanarak ağın yaşam süresinin üst sınırı artırılır ve daha fazla düğümün aktif olması sayesinde alandaki hedeflerin izlenmesindeki süreklilik sağlanmış olur. 


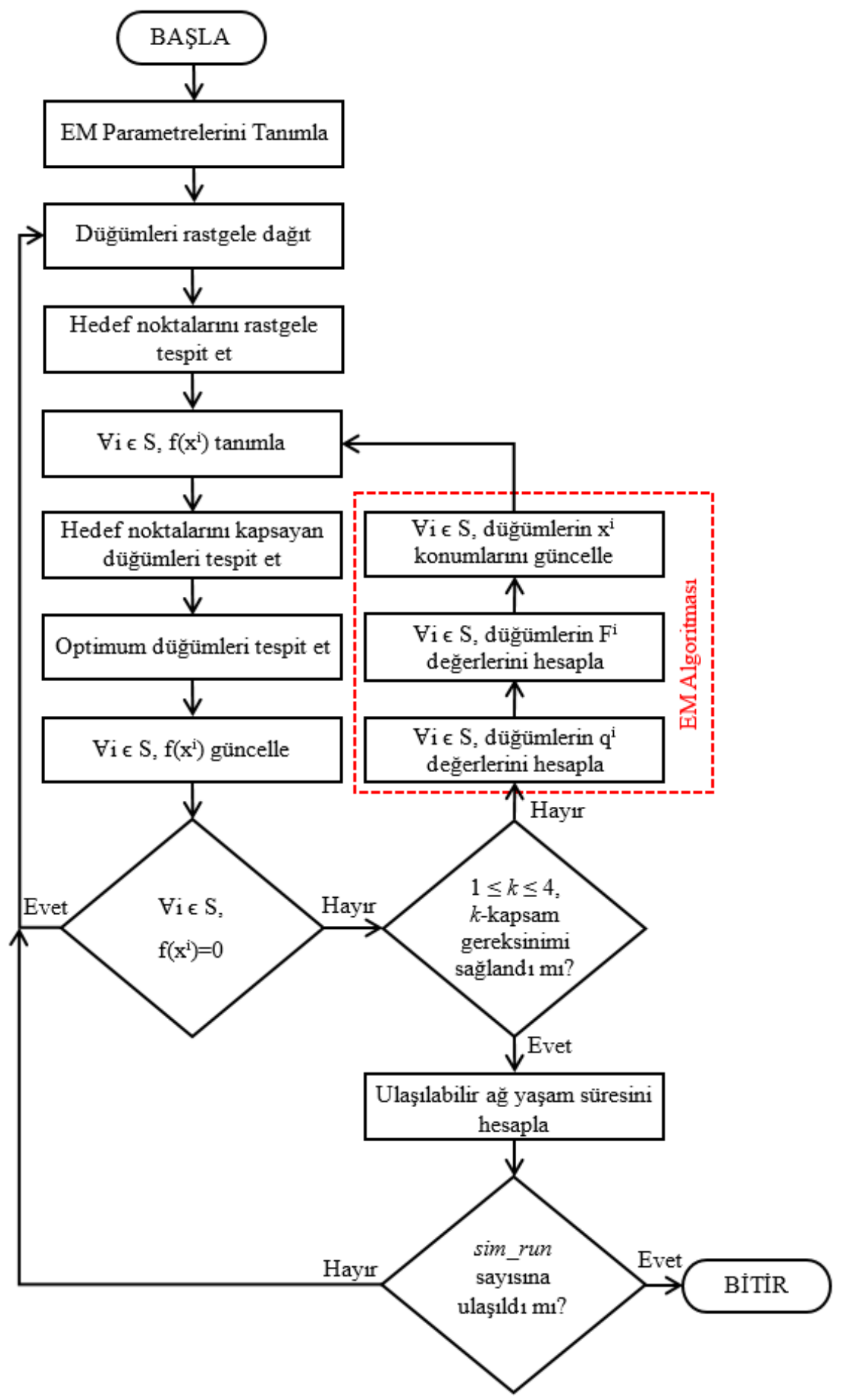

Şekil 2. TCAML-EM'nin akış diyagramı (Flowchart of the TCAML-EM)

\section{SONUCLAR VE TARTISMMALAR (RESULTS AND DISCUSSIONS)}

Geliştirilen algoritmanın benzetimleri MATLAB ${ }^{\circledR}$ kullanılarak yapılmıştır. TCAML-EM tarafından ulaşılan ağ yaşam süreleri düğümlerin rastgele dağıtımı, $\mathrm{ABC}$ ve $\mathrm{PSO}$ algoritmaları [3] ile karşılaştırılarak hedeflerin $k$-kapsam gereksiniminin sağlanmasında geliştirilen algoritmanın etkinliği ölçülmüştür.

\subsection{Rastgele Dă̆ıtım (Random Deployment)}

İlgili alandaki düğümlerin her bir iterasyondaki dağıtımları rastgele yapılarak hedef noktaların $k$-kapsam gereksinimini sağlama durumu tespit edilmiştir. $\mathrm{Bu}$ amaç ile rastgele dağıtım yöntemi diğer meta-sezgisel algoritmalar ile karşılaştırılarak hedeflerin $k$-kapsam gereksinimlerine göre ağın ulaşılabilir yaşam süresindeki performansı ölçülmüştür. 


\subsection{ABC ve PSO Tabanlı Dă̆ıtım}

(Deployment Based On ABC and PSO)

$\mathrm{Bu}$ çalışmada, meta-sezgisel olan $\mathrm{ABC}$ ve PSO algoritmalarının literatürdeki benzetim sonuçları geliștirilen TCAML-EM ile karşılaştırılmıştır. Tablo 5'de tanımlanan parametreler kullanilarak $\mathrm{ABC}$ ve PSO ile yapılan benzetimlerde hesaplanan ăg yaşam süreleri Tablo 6'da sunulmuştur.

\section{3. Önerilen Algoritma (Proposed Algorithm)}

TCAML-EM'nin benzetimleri Tablo 5'deki ortak parametreler kullanılarak yapılmıștır. Bu parametrelerden $A$ iki boyutlu ve toplam $250000 \mathrm{~m}^{2}$ olan ilgili alanı, $m 25$ ' er artış miktarıyla 100 ile 250 arasında dağıtılan mobil düğüm sayısını, $T$ ilgili alanda 15,20 ve 25 adet olarak tanımlanan ve konumları rastgele belirlenen hedeflerin sayısın göstermektedir. Ayrıca $r$ düğümlerin tarama yarıçap mesafesini, $E_{0}$ her bir düğümün dinamik dağıtım öncesindeki başlangıç enerji miktarını, $e_{i}$ ise dügümmlerin enerji tüketim miktarını temsil etmektedir. Her bir hedefin $k$-kapsam gereksinimleri 1 ile 4 arasında sağlanması koşuluyla birbirinden bağımsız olarak 5 Monte Carlo benzetimi yapılarak TCAML-EM ile ağın ulaşılabilir yaşam süresi optimize edilmeye çalışılmıştır.
Tablo 5. Benzetim parametreleri (Simulation parameters)

\begin{tabular}{ll}
\hline Parametre & Tanımlandığı değer veya aralık \\
\hline$A$ & $500 \times 500$ (en, boy) metre \\
$m$ & 100 ile 250 arasında \\
$T$ & $15,20,25$ adet \\
$r$ & 75 metre \\
$k$ & 1 ile 4 arasinda \\
sim_run & 5 Monte Carlo \\
$E_{0}$ & 100 birim \\
$e_{i}$ & 1 birim \\
\hline
\end{tabular}

$\mathrm{Bu}$ çalışmada, dağıtılan mobil düğüm sayısına göre $k$ kapsam gereksinimleri esas alınarak algoritmalar ile yapılan benzetimlerde ulaşılan ağ yaşam süreleri hesaplanmıştır. Tablo 6'da sunulan sonuçlara göre 25 adet hedefin her birinin $k$-kapsam gereksiniminin sağlanmasında TCAML$E M$ ile hesaplanan ulaşılabilir ağ yaşam süreleri $A B C$ ve PSO algoritmaları ile karşılaştırıldığında optimum sonuçlara elde edilmiştir. TCAML-EM, ABC ve PSO algoritmalarının ulaşılabilir ağ yaşam sürelerinin grafiksel olarak karşılaştırmaları Şekil 3 ile Şekil 6 arasında gösterilmiştir.

Tablo 6. TCAML-EM, ABC [3] ve PSO [3] algoritmaları kullanılarak T=25 için ağın ulaşılabilir yaşam sürelerinin benzetim sonuçları

(Simulation results of network's reachable lifetimes for T=25 using TCAML-EM, ABC [3] and PSO [3] algorithms)

\begin{tabular}{lllllllllllll}
\hline & $k \geq 1$ & \multicolumn{3}{c}{$k \geq 2$} & \multicolumn{3}{c}{$k \geq 3$} \\
\cline { 2 - 11 } & TCA & ABC & PSO & TCA & ABC & PSO & TCA & ABC & PSO & TCA & ABC & PSO \\
\hline 100 & 2322 & 700 & 700 & 2231 & 350 & 350 & 2061 & 233 & 233 & 1882 & 175 & 175 \\
150 & 2340 & 1100 & 1100 & 2271 & 550 & 550 & 2261 & 366 & 366 & 2231 & 275 & 275 \\
200 & 2347 & 1400 & 1340 & 2319 & 700 & 660 & 2313 & 466 & 466 & 2297 & 350 & 335 \\
250 & 2357 & 1820 & 1700 & 2336 & 910 & 854 & 2324 & 606 & 568 & 2321 & 455 & 427 \\
\hline
\end{tabular}

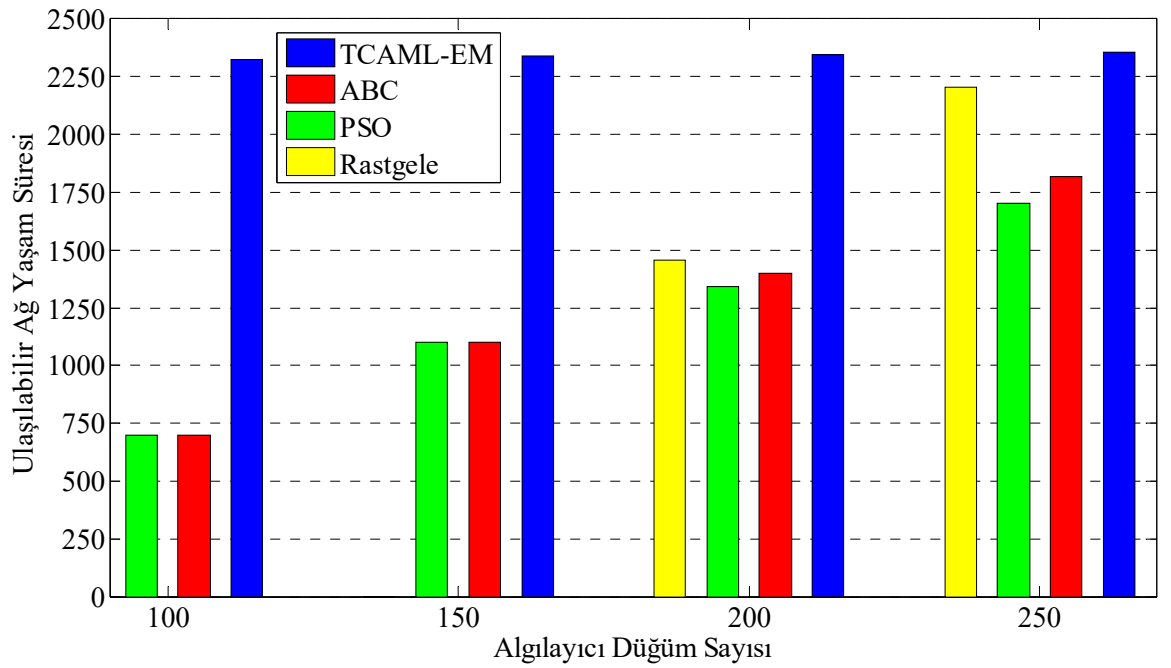

Şekil 3. $k \geq 1$ ve $T=25$ için ulaşılabilir ağ yaşam sürelerinin karşılaştırması (Comparison of reachable network lifetimes for $k \geq 1$ and $\mathrm{T}=25$ ) 
Tablo 5'deki benzetim parametreleri esas alınarak $k \geq 1$ ve T $=25$ olmak üzere 100 ve 150 adet düğüm ile yapılan rastgele dağıtımlarda dügümlerin tümü enerjilerini tamamıyla tükettiklerinden dolayı tüm hedeflerin basit kapsama gereksinimleri sağlanamadığı için ulaşılabilir ă̆ yaşam süreleri hesaplanamamıştır. 200 ve 250 adet düğümün rastgele dağıtılması durumunda ise, sadece basit kapsama gereksinimi sağlanarak Şekil 3'de gösterilmiştir. Basit kapsama haricinde $2 \leq k \leq 4$ aralığında tanımlanan $k$ kapsama gereksinimleri için 100 ile 250 aralığındaki düğ̈̈mlerin tümünün rastgele dağıtılması durumunda ise, düğümler enerjilerini tamamıyla tükettikleri için hedeflerin $k$-kapsam gereksinimleri sağlanamamıştır (Şekil 4, Şekil 5, Şekil 6). Benzetimlerde $k$-kapsam gereksinimi artırıldıkça tüm hedeflerin kapsam gereksinimlerinin sağlanabilmesi için düğümler daha fazla enerji tüketeceklerdir. Dolayısıyla ağın hesaplanan ulaşılabilir yaşam süresinde Şekil 4'te gösterildiği üzere karşılaştırılan her algoritmada bir miktar düşüş olacaktır. Fakat $k \geq 2$ ve $\mathrm{T}=25$ olmak üzere $100-250$ aralığında dağıtılan tüm düğümler için TCAML-EM ile ulaşılan ağ yaşam süresi ABC ve PSO'ya göre daima optimum olmuştur. Şekil 3 ile Şekil 6 arasındaki grafiklerde gösterildiği üzere ABC ve PSO algoritmaları için 100 ve 150 düğüm dağıtılarak tüm $k$-kapsama gereksinimleri sağlandığında hesaplanan ulaşılabilir ağ yaşam süreleri her iki algoritmada eşittir. 200 düğüm dağıtıldığında ise $k \geq 1, k$ $\geq 2$ ve $k \geq 4$ için $\mathrm{ABC}$ ile hesaplanan ulaşılabilir ağ yaşam sürelerinin PSO'dan daha iyi olduğu tespit edilmiştir. Ayrıca tüm $k$-kapsama gereksinimlerinin sağlanması için 250 düğüm dağıtılması durumunda $\mathrm{ABC}$ algoritması PSO'ya göre daima optimum ağ yaşam sürelerine ulaşmıştır.

Kapsama gereksinimleri $1 \leq k \leq 4$ olmak üzere $\mathrm{T}=25$ hedef noktası için rastgele dağıtım ile yapılan benzetimlerde sadece basit kapsama için aşırı sayıda düğümün dağıtılması durumunda hedeflerin kapsam gereksiniminin sağlandığ

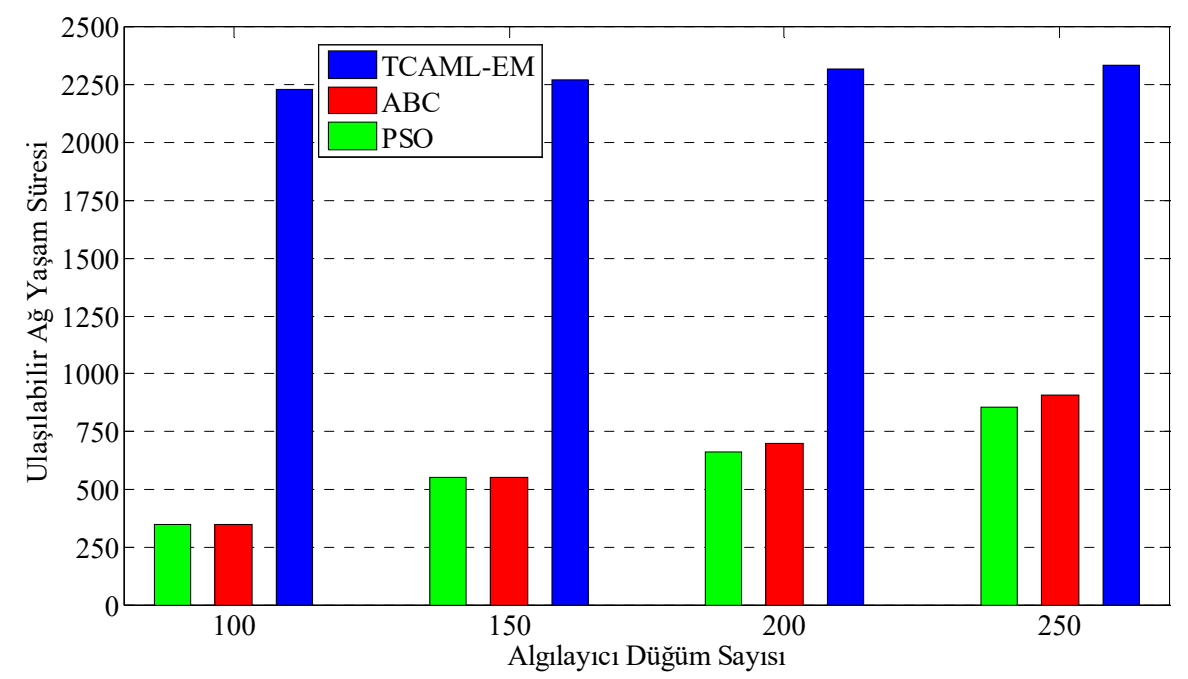

Şekil 4. $k \geq 2$ ve $\mathrm{T}=25$ için ortalama ağ yaşam sürelerinin karşılaştırması (Comparison of reachable network lifetimes for $k \geq 2$ and $\mathrm{T}=25$ )

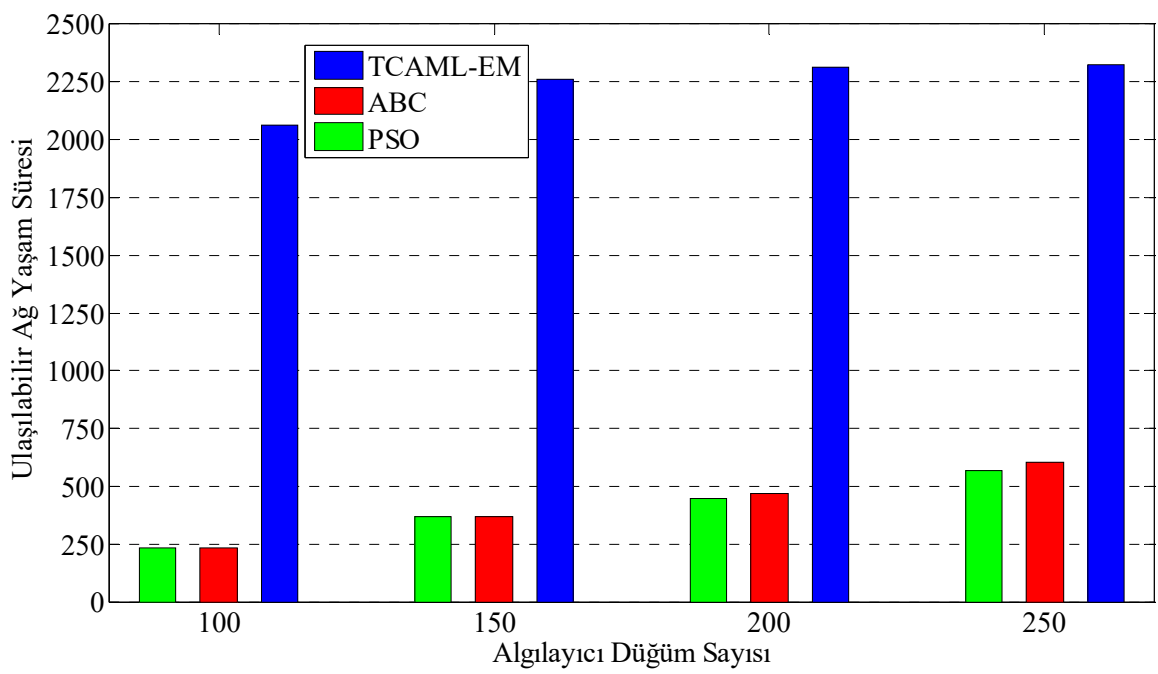

Şekil 5. $k \geq 3$ ve $\mathrm{T}=25$ için ortalama ağ yaşam sürelerinin karşılaştırması (Comparison of reachable network lifetimes for $k \geq 3$ and $\mathrm{T}=25$ ) 
Şekil 3'teki karşılaştırmadan tespit edilmiştir. Fakat aşırı sayıda dügümün rastgele olarak dağıtılması hem gereksiz yere düğ̈ümlerde aşırı enerji tüketimine hem de düğümlerde bir çakışma alanı (overlapping area) oluşumuna sebep olacaktır. $\mathrm{Bu}$ nedenle rastgele dağıtım düğümlerin pil ömürlerini hızlı bir şekilde tüketerek ağın yaşam süresini olumsuz yönde etkileyecektir. TCAML-EM ile yapılan benzetimlerde 100 - 250 arasında düğümün dinamik olarak dağıtılması durumunda tüm $k$-kapsam gereksinimlerinin sağlandığı ve karşılaştırılan $\mathrm{ABC}$, PSO ve rastgele dağıtım yöntemine göre daima optimum ulaş1labilir ağ yaşam süresinin elde edildiği Şekil 3 ile Şekil 6 arasındaki grafiklerden tespit edilmiştir. Geliştirilen TCAML-EM ile alandaki bağımsız hedef sayıları için her bir $k$-kapsama gereksinimine ve dağıtılan düğüm sayılarına göre hesaplanan ulaşılabilir ağ yaşam sürelerinin karşılaştırılması Şekil 7 ile Şekil 9 arasında gösterilmiştir. Bu grafiklerde ağın maksimum yaşam süresinin $\mathrm{T}=25$ için 2500 birim, $\mathrm{T}=20$ için 2000 birim ve $\mathrm{T}=15$ için 1500 birim olduğu gösterilmiştir. $\mathrm{T}=25$ için hesaplanan ve Tablo 7'de gösterilen benzetim sonuçlarına göre TCAML-EM ile hesaplanan ulaşılabilir ă̆ yaşam süreleri Şekil 7'de karşılaştırılmıştır. $\mathrm{T}=20$ için hesaplanan ve Tablo 8'de gösterilerin benzetim sonuçlarına göre TCAML-EM ile hesaplanan ulaş1labilir ağ yaşam süreleri Şekil 8'de karşılaştırılmıştır. T = 15 için hesaplanan ve Tablo 9' de gösterilerin benzetim sonuçlarına göre TCAML-EM ile hesaplanan ulaşılabilir ağ yaşam süreleri Şekil 9'da karşılaştırılmıştır. Şekil 7 ile Şekil 9 arasında gösterilen grafiklere göre hedef sayısı esas alınarak ağın maksimum yaşam süresine optimum olarak yakınsamanın $k \geq 1$ olarak tanımlanması durumunda gerçekleşebileceği tespit edilmiştir. Ayrıca $k$-kapsam gereksiniminin artırılması, tüm hedeflerin kapsanmasını gittikçe zorlaştıracağı için düğümlerin enerji tüketimlerinin artmasına ve ulaşılabilir ağ yaşam süresinin düşmesine neden olacaktır. Şekil 10 ile Şekil 13 arasında gösterilen grafiklerde $\mathrm{T}=25$ için $1 \leq k \leq 4$ aralığındaki kapsam gereksinimi sağlanıncaya kadar düğümlerin dinamik dağıtımı yapılarak algılayıcıların ilgili alandaki konumları gösterilmiştir.

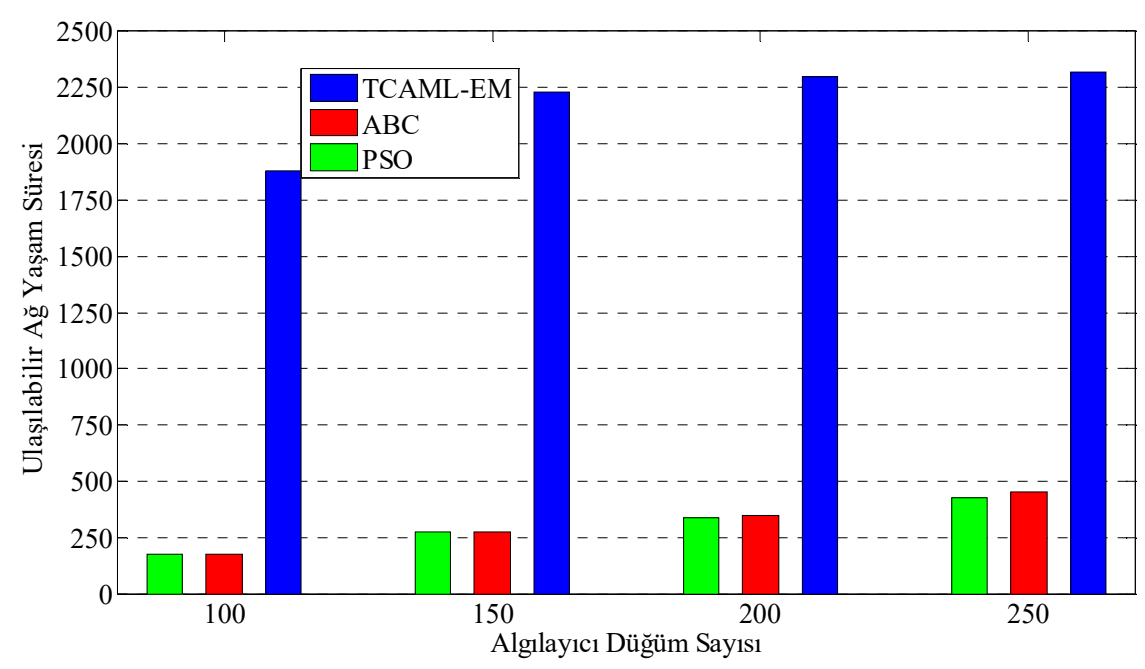

Şekil 6. $k \geq 4$ ve $\mathrm{T}=25$ için ortalama ağ yaşam sürelerinin karşılaştırması (Comparison of reachable network lifetimes for $k \geq 4$ and $\mathrm{T}=25$ )

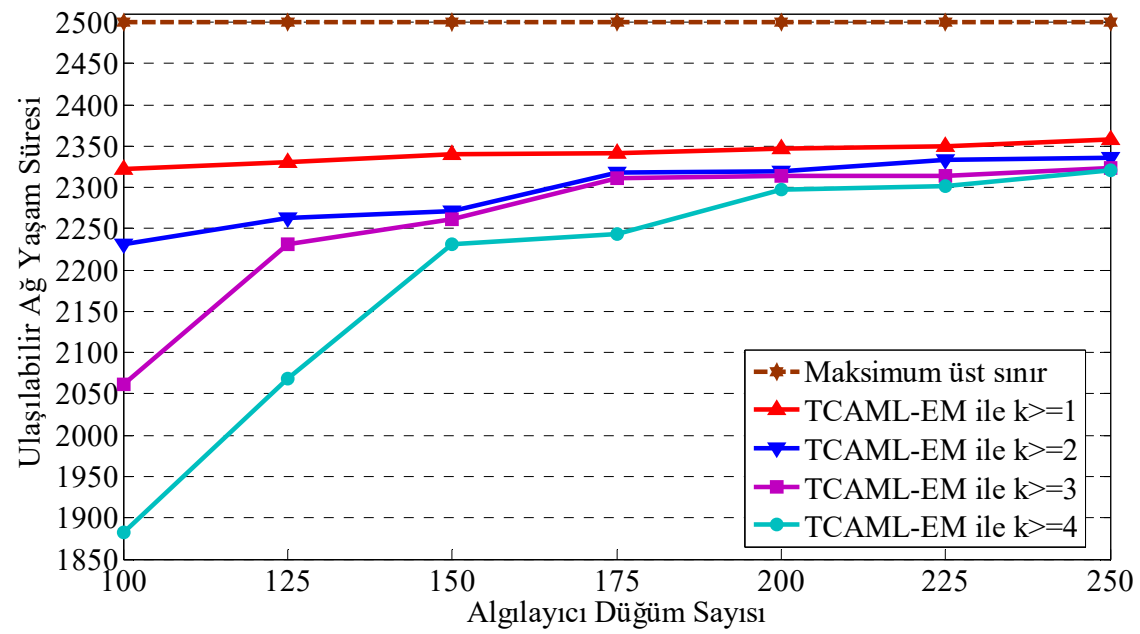

Şekil 7. T = 25 için algılayıcı sayısı ve $k$-kapsama derecelerine göre TCAML-EM'nin ulaşılabilir ağ yaşam süreleri (TCAML-EM's reachable network lifetimes according to sensor number and $k$-coverage degrees for $\mathrm{T}=25$ ) 
Tablo 7. TCAML-EM kullanılarak $\mathrm{T}=25$ için ağın ulaşılabilir yaşam sürelerinin benzetim sonuçları (Simulation results of network's reachable lifetimes for $\mathrm{T}=25$ using TCAML-EM)

\begin{tabular}{lllll}
\hline$m$ & $k \geq 1$ & $k \geq 2$ & $k \geq 3$ & $k \geq 4$ \\
\hline 100 & 2322.250 & 2231.667 & 2061.024 & 1882.000 \\
125 & 2330.363 & 2262.833 & 2231.875 & 2068.133 \\
150 & 2340.681 & 2271.500 & 2261.250 & 2231.199 \\
175 & 2341.071 & 2317.418 & 2311.782 & 2243.056 \\
200 & 2347.509 & 2319.809 & 2313.810 & 2297.785 \\
225 & 2349.989 & 2332.711 & 2313.817 & 2302.176 \\
250 & 2357.750 & 2336.460 & 2324.048 & 2321.013 \\
\hline
\end{tabular}

Tablo 8. TCAML-EM kullanılarak $T=20$ için ağın ulaşılabilir yaşam sürelerinin benzetim sonuçları (Simulation results of network's reachable lifetimes for $T=20$ using TCAML-EM)

\begin{tabular}{lllll}
\hline$m$ & $k \geq 1$ & $k \geq 2$ & $k \geq 3$ & $k \geq 4$ \\
\hline 100 & 1860.000 & 1830.400 & 1718.000 & 1666.200 \\
125 & 1863.778 & 1836.381 & 1763.286 & 1724.133 \\
150 & 1875.939 & 1865.533 & 1840.286 & 1780.795 \\
175 & 1883.011 & 1865.667 & 1843.492 & 1833.667 \\
200 & 1887.233 & 1881.566 & 1855.250 & 1847.525 \\
225 & 1887.500 & 1881.767 & 1862.800 & 1857.667 \\
250 & 1894.667 & 1881.581 & 1867.678 & 1863.992 \\
\hline
\end{tabular}

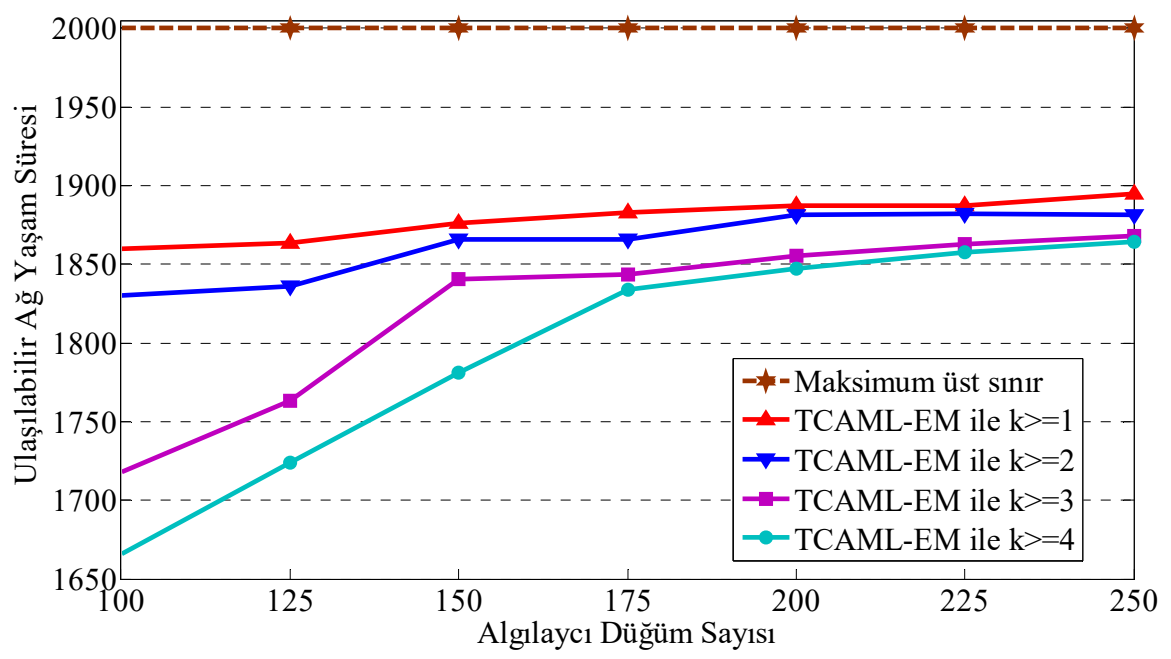

Şekil 8. $T=20$ için algılayıcı sayısı ve $k$-kapsama derecelerine göre TCAML-EM'nin ulaşılabilir ağ yaşam süreleri (TCAML-EM's reachable network lifetimes according to sensor number and $k$-coverage degrees for $\mathrm{T}=20$ )

Tablo 9. TCAML-EM kullanılarak $\mathrm{T}=15$ için ağın ulaşılabilir yaşam sürelerinin benzetim sonuçları (Simulation results of network's reachable lifetimes for T $=15$ using TCAML-EM)

\begin{tabular}{lllll}
\hline$m$ & $k \geq 1$ & $k \geq 2$ & $k \geq 3$ & $k \geq 4$ \\
\hline 100 & 1409.196 & 1376.700 & 1308.029 & 1278.848 \\
125 & 1420.221 & 1393.200 & 1382.830 & 1363.875 \\
150 & 1423.837 & 1399.750 & 1397.343 & 1375.358 \\
175 & 1424.500 & 1410.500 & 1403.581 & 1394.846 \\
200 & 1429.200 & 1417.068 & 1406.500 & 1401.288 \\
225 & 1432.250 & 1424.250 & 1412.875 & 1405.476 \\
250 & 1436.291 & 1430.878 & 1420.052 & 1418.005 \\
\hline
\end{tabular}




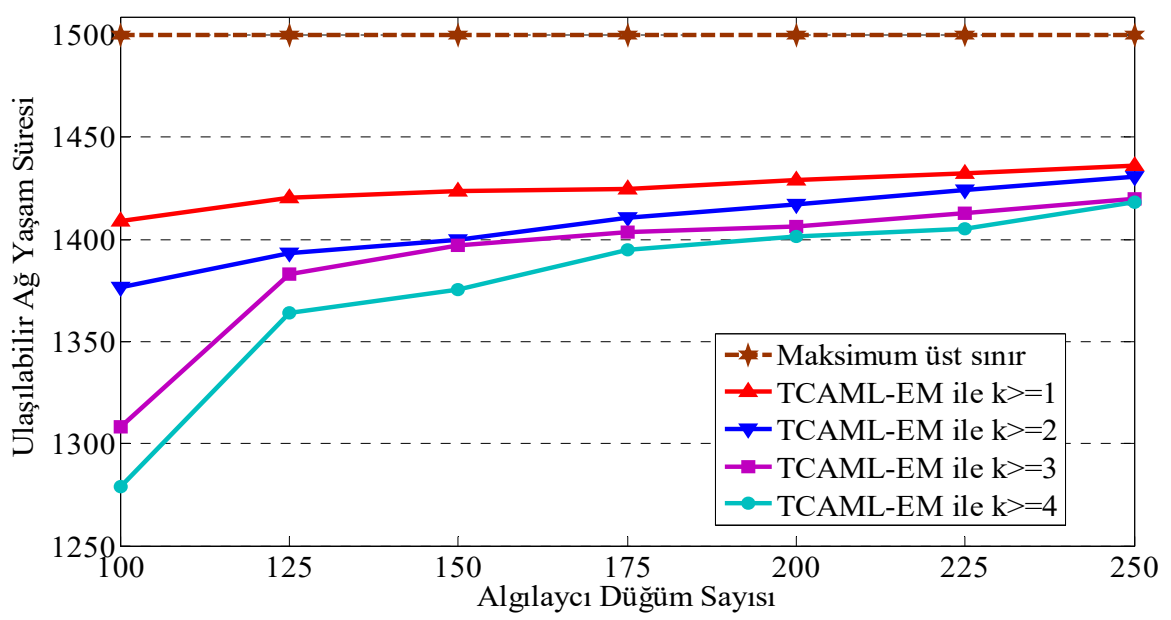

Şekil 9. $\mathrm{T}=15$ için algılayıcı sayısı ve $k$-kapsama derecelerine göre TCAML-EM'nin ulaşılabilir ağ yaşam süreleri (TCAML-EM's reachable network lifetimes according to sensor number and $k$-coverage degree for $\mathrm{T}=15$ )

$\mathrm{Bu}$ grafiklerde rastgele dağıtılan hedefler yıldız simgesi ile, $k$-kapsam gereksinimini sağlayarak hedef noktasını kapsayan optimum olan dügüumler yeşil nokta ile, optimum olmayan düğümler ise kırmızı nokta ile temsil edilmiştir. Şekil 10 ile Şekil 13 arasındaki grafiklere göre $k$-kapsam gereksinimi artırıldıkça birbirinden bağımsız olarak ilgili alanda rastgele konumlanan hedef noktalarını kapsayan ve yeşil nokta olarak temsil edilen düğümler optimum olur. Hedef noktaların $k$-kapsam gereksinimleri sağlandığ itibaren optimum olmayan düğümler bu hedef noktalarını kapsamaya devam eder ise, kırmızı nokta olarak temsil edilen bu düğümler $k$-kapsam gereksinimini sağlayıncaya kadar iterasyonlarda konum değiştirmeye devam eder. Bu sebeple bazı hedef noktaların optimum olmayan düğ̈̈mler tarafından kapsanması hedeflerin $k$-kapsam gereksiniminin sağlanmasında bu düğümlerin hiçbir etkisinin olmadığını gösterir. Fakat optimum olmayan düğümlerin gereksiz olarak hedefleri kapsaması bu düğümlerin enerji tüketimlerini artırarak ağdaki yaşam sürelerinin olumsuz yönde etkilenmesine sebep olur.

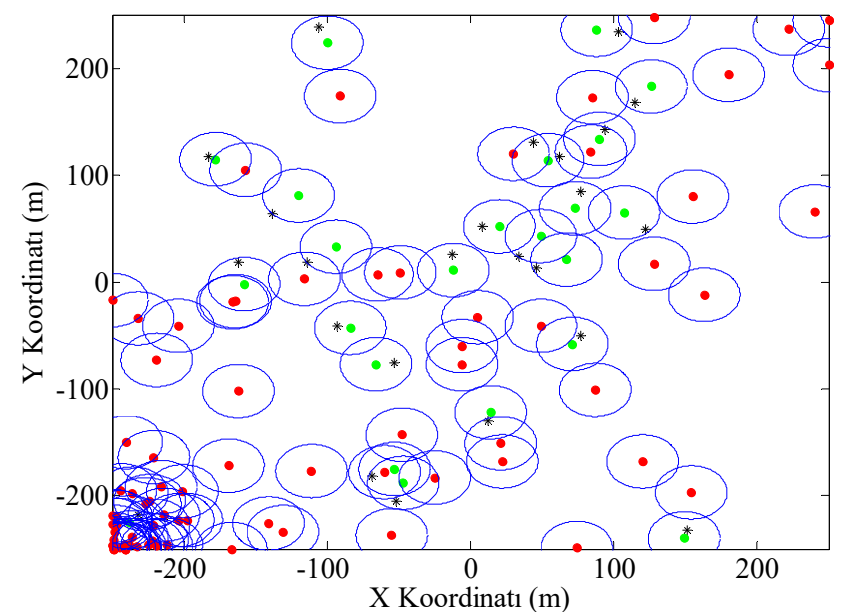

Şekil 10. TCAML-EM kullanılarak T=25 ve $k \geq 1$ için 100 düğümün ilgili alandaki dinamik dağıtımı

(Dynamic distribution in the field of interest of 100 nodes for $\mathrm{T}=25$ and $k$ $\geq 1$ using TCAML-EM)

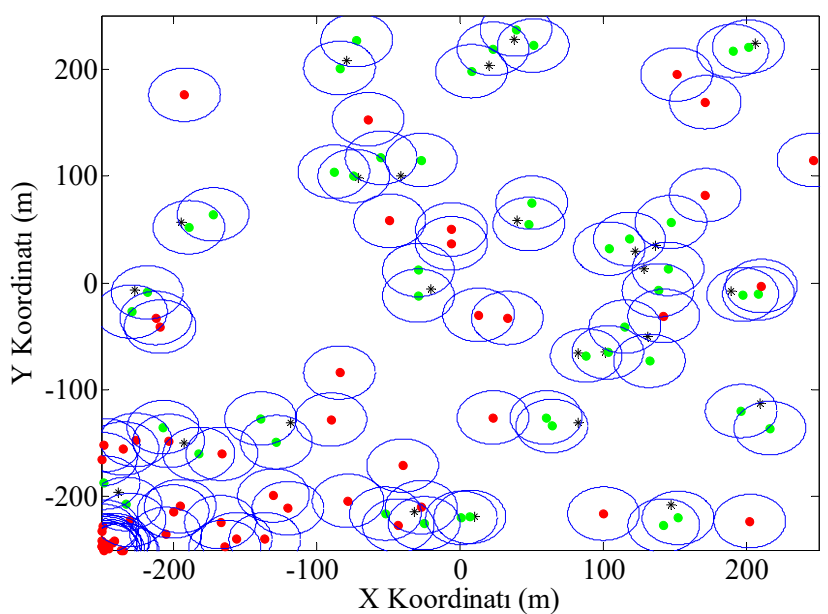

Şekil 11. TCAML-EM kullanılarak $T=25$ ve $k \geq 2$ için 100 düğümün ilgili alandaki dinamik dağıtımı

(Dynamic distribution in the field of interest of 100 nodes for $\mathrm{T}=25$ and $k$ $\geq 2$ using TCAML-EM)

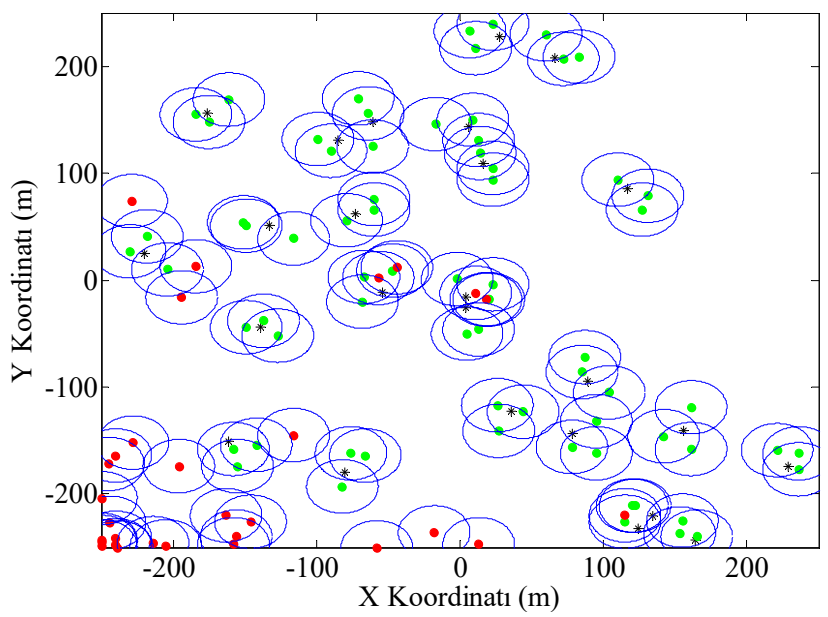

Şekil 12. TCAML-EM kullanılarak $\mathrm{T}=25$ ve $k \geq 3$ için 100 düğümün ilgili alandaki dinamik dağıtımı

(Dynamic distribution in the field of interest of 100 nodes for $\mathrm{T}=25$ and $k$ $\geq 3$ using TCAML-EM) 


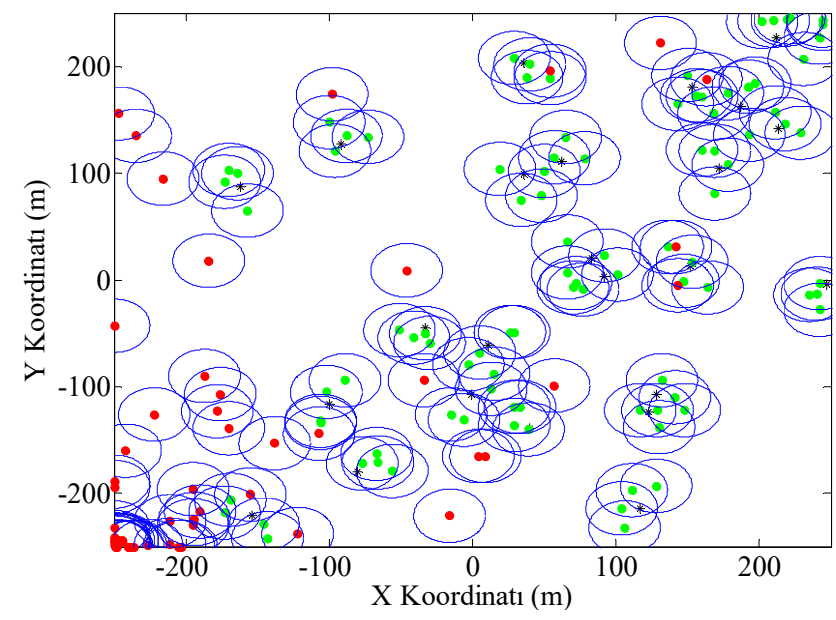

Şekil 13. TCAML-EM kullanılarak $\mathrm{T}=25$ için $k \geq 4$ olmak üzere 150 düğ̈̈mün ilgili alandaki dinamik dağıtımı (Dynamic distribution in the field of interest of 100 nodes for $\mathrm{T}=25$ and $k$ $\geq 4$ using TCAML-EM)

\section{SONUÇLAR (CONCLUSIONS)}

Bu çalışmada, geliştirilen TCAML-EM ile ağın maksimum yaşam süresine ulaşabilmek için hedeflerin $1 \leq k \leq 4$ aralığında $k$-kapsam gereksinimlerinin sağlanması şartıyla düğümlerin dinamik dağıtımları yapılmıştır. Geliştirilen TCAML-EM, literatürdeki ABC ve PSO algoritmaları ve rastgele dağıtım yöntemi tarafından ağın ulaşılabilir yaşam süreleri hesaplanarak algoritmaların karşılaştırılması yapılmıştır. Rastgele dağıtımın sadece $k \geq 1$ olmak üzere 200 ve 250 adet düğümün dağıtılması durumunda hedeflerin kapsam gereksinimlerini sağlayabileceği sonucuna ulaşılmıştır. Ayrıca rastgele dağıtım yöntemi ile az sayıda düğümün dağıtılması durumunda tüm hedeflerin $k$-kapsam gereksinimlerinin sağlanamadığı, aşırı sayıda düğümün dağıtılması durumunda ise basit kapsama hariç tanımlanan diğer $k$-kapsam gereksinimlerinin sağlanamadığı ve bu nedenle tüm düğümlerin yaşam sürelerinin tamamiyla tükendiği gözlemlenmiştir. Dolayısıyla rastgele dağıtım yöntemi ile hedeflerin $k$-kapsam gereksinimlerinin sağlanması ve ağın ulaşılabilir yaşam süresinin optimize edilmesi mümkün değildir.

TCAML-EM ile $1 \leq k \leq 4$ aralığında tanımlanan $k$-kapsam gereksinimleri esas alınarak yapılan Monte Carlo benzetim çalışmalarında elde edilen deneysel bulgular değerlendirilerek literatürdeki ABC ve PSO algoritmaları ile karşılaştırıldığında geliştirilen algoritma ile daha optimum ağ yaşam sürelerine ulaşılmıştır. İlgili alanda birbirinden bağımsız olarak tanımlanan tüm hedeflerin $k$-kapsam gereksinimleri sağlanarak dügümlerin dinamik dağıtımlarını yapan yeni bir meta-sezgisel yöntem ile ağın ulaşılabilir yaşam süresinin optimize edilebileceği gösterilmiştir. Ayrıca geliştirilen TCAML-EM ile hedef noktaların gereğinden fazla dügüm tarafından kapsanması minimize edilerek hem düğümlerin enerji tüketimlerini azaltmaya hem de ağın yaşam süresini artırmaya yönelik bir katkı sağlamıştır. Bu çalışmada, hedeflerin $k$-kapsam gereksinimlerini hızlı bir şekilde sağlayarak ağın ulaşılabilir yaşam süresini optimuma doğru yakınsamasını sağlayan yeni bir yöntem olarak TCAML-EM önerilmekte ve literatüre katkı sağlayacağ düşünülmektedir. Çalışmanın sonraki aşamasında kümeleme yöntemi ile düğümlerin yönlendirilmesi sağlanarak düğümlerin enerji tüketimleri minimize edilecektir.

\section{SIMMGELER (SYMBOLS)}

$A \quad$ İlgili alanın metrekare olarak alan büyüklüğü

$b_{i} \quad$ Dügümün mevcut pil gücü

$d \quad$ Öklid mesafesi

$e_{i} \quad$ Düğümün enerji tüketim oranı

$E_{0} \quad$ Düğümün başlangıç enerjisi

$f(x) \quad$ Parçacıkların uygunluk fonksiyon değeri

$F \quad$ Parçacıklara uygulanan kuvvet değeri

$l_{c u} \quad$ Çözüm uzayı alt sınır koordinatı

$m \quad$ Algılayıcı düğüm sayısı

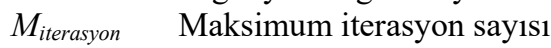

$n_{c u} \quad$ Çözüm uzayının boyutu

$N_{p r t} \quad$ Çözüm uzayının popülasyon sayısı

$q \quad$ Parçacıkların yük değeri

$Q \quad$ Kapsam vektörü

$r \quad$ Algılayıcı tarama yarıçapı

sim_run Monte-Carlo benzetim say1s1

$S \quad$ Algılayıcı düğüm kümesi

$t \quad$ Hedef nokta sayıs1

$T \quad$ Hedef nokta kümesi

$u_{c u} \quad$ Çözüm uzayı üst sınır koordinatı

$U \quad$ Ağın yaşam süresinin üst sınır değeri

$x \quad$ Çözüm uzayındaki parçacıkların koordinatı

$x^{\text {opt }} \quad$ Çözüm uzayındaki optimum parçacığın

$\lambda \quad$ Rastgele adım uzunluğu

\section{KAYNAKLAR (REFERENCES)}

1. Özdağ R., The Solution of the $k$-coverage Problem in Wireless Sensor Networks, 24th Signal Processing and Communications Applications Conference, Zonguldak, Turkey, 873-876, 16-19 May 2016.

2. Chong C.Y., Kumar S.P., Sensor networks: Evolution, Opportunities, and Challenges, Proc. IEEE, 91 (8), 1247-1256, 2003.

3. Mini S., Udgata S.K., Sabat S.L., Sensor Deployment and Scheduling for Target Coverage Problem in Wireless Sensor Networks, IEEE Sens. J., 14 (3), 636644, 2014.

4. Chaudhary M., Pujari A.K., Q-coverage Problem in Wireless Sensor Networks, 10th International Conference on Distributed Computing and Networking, Hyderabad, India, 325-330, 3-6 January 2009.

5. Li Y., Gao S., Designing k-coverage Schedules in Wireless Sensor Networks. J. Comb. Opt., 15 (2), $127-$ 146, 2008.

6. Gu Y., Liu H., Zhao B., Target Coverage with QoS Requirements in Wireless Sensor Networks, The 2007 International Conference on Intelligent Pervasive Computing, Jeju, South Korea, 35-38, 11-13 October 2007. 
7. Öztürk C., Karaboğa D., Görkemli B., Artificial Bee Colony Algorithm for Dynamic Deployment of Wireless Sensor Networks, Turk. J. Elec. Eng. Comp. Sci., 20 (2), 255-262, 2012.

8. Öztürk C., Karaboğa D., Görkemli B., Probabilistic Dynamic Deployment of Wireless Sensor Networks by Artificial Bee Colony Algorithm, Sensors, 11 (6), 60566065, 2011.

9. Özdağ R., Karcı A., Sensor Node Deployment Based on Electromagnetism-Like Algorithm in Mobile Wireless Sensor Networks, Int. J. Distrib. Sens. Netw., 2015, 15, 2015.

10. Özdağ R., Karcı A., Probabilistic Dynamic Distribution of Wireless Sensor Networks with Improved Distribution Method based on Electromagnetism-Like Algorithm, Measurement, 79, 66-76, 2016.

11. Okay F.Y., Özdemir S., Improving Coverage in Wireless Sensor Networks Using Multi-objective Evolutionary Algorithms, Journal of the Faculty of Engineering and Architecture of Gazi University, 30 (2), 143-153, 2015.

12. Onur E., Ersoy C., Deliç H., Quality of Deployment in Surveillance Wireless Sensor Networks, Int. J. Wireless Inf. Networks, 12 (1), 61-67, 2005.

13. Cheng Z., Perillo M., Heinzelman W.B., General Network Lifetime and Cost Models for Evaluating Sensor Network Deployment Strategies, IEEE Trans. Mob. Comput., 7 (4), 484-497, 2008.

14. Akbas A., Yildiz H.U., Tavli B., Uludag S., Joint Optimization of Transmission Power Level and Packet Size for WSN Lifetime Maximization, IEEE Sens. J., 16 (12), 5084-5094, 2016.

15. Mini S., Udgata S.K., Sabat S.L., Sensor Deployment in 3-D Terrain Using Artificial Bee Colony Algorithm, First International Conference on Swarm, Evolutionary, and Memetic, Chennai, India, 424-431, 16-18 December 2010.

16. Mini S., Udgata S.K., Sabat S.L., Artificial Bee Colony Based Sensor Deployment Algorithm for Target Coverage Problem in 3-D Terrain, International Conference on Distributed Computing and Internet Technology, Bhubaneshwar, India, 313-324, 9-12 February 2011.
17. Udgata S.K., Sabat S.L., Mini S., Sensor Deployment in Irregular Terrain Using Artificial Bee Colony Algorithm, World Congress on Nature Biologically Inspired Computing, Coimbatore, India, 1309-1314, 911 December 2009.

18. Mini S., Udgata S.K., Sabat S.L., A Heuristic to Maximize Network Lifetime for Target Coverage Problem in Wireless Sensor Networks, Ad Hoc Sensor Wireless Netw., 13 (3-4), 251-269, 2011.

19. Liu H., Wan P., Jia X., Maximal Lifetime Scheduling for Sensor Surveillance Systems with K Sensors to One Target, IEEE Trans. Parallel Distrib. Syst., 17 (12), 1526-1536, 2006

20. Liu H., Jia X., Wan P.J., Yi C.W., Makki S.K., Pissinou N., Maximizing Lifetime of Sensor Surveillance Systems, IEEE/ACM Trans. Networking, 15 (2), 334345, 2007.

21. Birbil S.I., Fang S.C., An Electromagnetism-like Mechanism for Global Optimization, J. Global Optim., 25 (3), 263-282, 2003.

22. Canayaz M., Karci A., Cricket Behaviour-based Evolutionary Computation Technique in Solving Engineering Optimization Problems, Appl. Intell., 44 (2), 362-376, 2015.

23. Akyol S., Alataş B., Automatic Mining of Accurate and Comprehensible Numerical Classification Rules with Cat Swarm Optimization Algorithm, Journal of the Faculty of Engineering and Architecture of Gazi University, 31 (4), 839-857, 2016.

24. Özdağ R., Karc1 A., Elektromagnetizma-Like Algoritması ile Kablosuz Algılayıcı Ağların Olasılıksal Dinamik Dağıtımları, 2nd International Symposium On Innovative Technologies in Engineering and Science, Karabük, Turkey, 368-377, 18-20 June 2014.

25. Özdağ R., Karc1 A., A Novel Routing Protocol Based on EM-L Algorithm for Energy Efficiency of Wireless Sensor Networks, 23th Signal Processing and Communications Applications Conference, Malatya, Turkey, 871-874, 16-19 May 2015.

26. Lee C.H., Chang F.K., Lee Y.C., An Improved Electromagnetism-like Algorithm for Recurrent Neural Fuzzy Controller Design, Int. J. Fuzzy Syst., 12 (4), 280290,2010 . 
